\title{
Technical and economic indices that determine the profitability of milk production systems participating in the "Full Bucket" program
}

\section{Índices técnicos e econômicos determinantes da lucratividade em sistemas de produção de leite participantes do programa "Balde Cheio"}

\author{
Fábio Raphael Pascoti Bruhn'; Marcos Aurélio Lopes²; \\ Flávio de Moraes ${ }^{3}$; Afonso Aurélio de Carvalho Peres ${ }^{4}$
}

\begin{abstract}
This study assesses the relationships among net margin (ML), profitability (LUC), and return (RENT), as well as several technical and economic indices that determine the ML, LUC and RENT land-use change, and economic return of milk production systems. We estimate and analyze the property-size, zootechnical, and economic indices of 20 milk production systems located in the state of Rio de Janeiro, Brazil, in 2011. We also conduct a descriptive analysis of the variables studied, as well as a multiple linear regression analysis among the estimated indices (independent variables) and the net margin, profitability, and return (dependent variables). The statistical analyses were performed using SPSS 20.0. The items that most influenced net margin were milk production by labor, total revenue, energy and protein commercial concentrates, and the ratio of labor costs to total operating costs. Then, profitability was most influenced by animal productivity per day, fixed value by lactation matrix (value immobilized in the activity divided by the number of lactating matrices), milk revenue, and the representativeness of energy concentrates. Economic returns were most influenced by the number of males available for sale, as well as by animal productivity per day and the value of assets on land per hectare. These findings show that management and technological efforts are required to reduce production costs. In addition, animal productivity needs to be increased because it is has the highest positive relationship with profitability.
\end{abstract}

Key words: Profitability analysis. Cost of production. Dairy farming.

\section{Resumo}

Objetivou-se avaliar a relação existente entre a margem líquida (ML), lucratividade (LUC) e a rentabilidade (RENT) e alguns índices técnicos e econômicos determinantes da ML, LUC e RENT de sistemas de produção de leite. Foram estimados e analisados índices de tamanho da propriedade, zootécnicos e econômicos de 20 sistemas de produção de leite localizados no estado do Rio de Janeiro, Brasil, no ano de 2011. Foram realizadas análises descritivas das variáveis estudadas, assim como análises de regressão linear multiple entre os índices estimados (variáveis independentes) e a margem líquida, lucratividade e a rentabilidade (variáveis dependentes). As análises estatísticas foram realizadas utilizando o software SPSS 20.0. Os itens que mais influenciaram positivamente a margem líquida foram a produção de leite por mão de obra, a receita total, os concentrados energético e proteico

\footnotetext{
${ }^{1}$ Prof. Adjunto, Centro de Controle de Zoonoses, Universidade Federal de Pelotas, UFPel, RS, Brasil. E-mail: fabio_rpb@yahoo. com.br

2 Prof. Titular, Departamento de Medicina Veterinária. Universidade Federal de Lavras, UFLA, Lavras, MG, Brasil. E-mail: malopes@dmv.ufla.br

3 M.e em Ciências Veterinárias, DMV, UFLA, Lavras, MG, Brasil. E-mail: f.demoraes2009@gmail.com

${ }^{4}$ Prof. Adjunto, Universidade Federal Fluminense, UFF, Volta Redonda, RJ, Brasil. E-mail: lelo@metal.eeimvr.uff.br

* Author for correspondence
} 
comercial e a proporção do custo da mão de obra em relação ao custo total da atividade, enquanto que a produtividade animal por dia, o valor imobilizado por matriz em lactação (valor imobilizado na atividade dividido pela quantidade de matrizes em lactação), a receita do leite e a representatividade do concentrado energético foram os itens que mais influenciaram positivamente a lucratividade. Quanto à rentabilidade, os itens que mais influenciaram positivamente foram a quantidade de machos disponíveis para a venda, a produtividade animal por dia e o valor da terra, por hectare.

Palavras-chave: Análise de rentabilidade. Custo de produção. Pecuária leiteira.

\section{Introduction}

Dairy farming profitability, defined as business efficiency to generate profit, is related to an isolated effect and to the interaction among several variables, particularly those inherent to the zootechnical and management characteristics (in addition to the economic characteristics) of dairy properties.

The definitions of technical and economic indicators related to profitability in a specific period provide cattle farmers with information relevant to making strategic decisions. By identifying the most important indicators, cattle farmers can prevent future errors that could cause significant economic loss and impair their operations.

Several studies carried out in Brazilian regions have evaluated indicators that focus on the technical efficiency of milk production. Oliveira et al. (2007) identify and quantify reference indicators of nine production systems in the south of Bahia. Lopes et al. (2004a) evaluate the profitability of dairy farming in the Lavras/MG region, and identify those components that have the greatest impact on the final costs of the activity. In addition, the authors identify the break-even points of 16 milk production systems. Schiffler et al. (1999) study zootechnical and productive indices, production costs, and the profitability of four milk production systems in the state of São Paulo. The afore mentioned studies all identify the need for regional studies, as well as for periodic identification and quantification of the indices. Moreover, they highlight the importance of identifying meaningful indicators of the economic efficiency of milk production, as we do in this study, because these will help to make local dairy farming feasible.
The "Full Bucket" program, developed by the Southeastern Livestock Research Center (CPPSE) of the Brazilian Agricultural Research Corporation (EMBRAPA) in São Carlos, São Paulo, arose from the need to meet with unproductive dairy producers, train professionals in rural extensions and farmers, and promote information exchange on technologies applied regionally. In addition, the program monitors the environmental, economic, and social impacts on production systems that adopt the proposed technologies (BORGES et al., 2011). This project teaches technicians and producers about technology that can be used on dairy properties in demonstration units, where they learn sustainable practices that can increase milk production. These include technology related to the production of high quality forage, gradually introducing specialized cows into the herd, simplified herd management systems, and the financial management of dairy farming activities. Moreover, since its implementation in Brazil in 2012, the project has been active in almost all the country's states (with the exception of Roraima), including 550 municipalities and approximately 4,000 properties. In addition 200 extension agents have been trained and approximately 600 more are being trained (CAMARGO; NOVO, 2012).

Several researchers have examined how to estimate production costs, and have studied the economic viability of milk production in Brazil (SCHIFFLER et al., 1999; LOPES et al., 2004a; CARVALHO et al., 2009; LOPES et al., 2009; LIMA et al., 2012; TEIXEIRA JÚNIOR et al., 2016). However, few studies have evaluated the relationships between technical and economic indices. This study was motivated by the importance of the "Full Bucket" program to the country and to 
the State of Rio de Janeiro, and by the scarcity of scientific studies on milk production systems assisted by the program and on the relationships between technical and economic indices. Here, we identify and analyze the determinants of the technical and economic indicators of the net margins, profitability, and returns of milk production systems participating in the "Full Bucket" program in several regions in the state of Rio de Janeiro.

\section{Materials and Methods}

The data analyzed were from 20 milk production systems, called demonstration units (DUs), of "Full Bucket" program participants located in the state of Rio de Janeiro in 2011. The municipality of Natividade represents two DUs; Valença, Carmo, and Campos dos Goitacazes have three each, and Quatis, Barra Mansa, Barra do Piraí, Paraíba do Sul, Santa Maria Madalena, Aperibé, Conceição de Macabu, Itaperuna, and Varresai have one DU each. The analyzed DUs were chosen using nonprobability sampling by judgment, considering the following criteria: the availability and quality of husbandry and financial data; consent and interest of cattle farmers in the research; and the ease of access to data. Data were recorded by cattle farmers in field notebooks throughout the year, and collected each month by the technician responsible for the DU.

As indicators of economic returns, we adopted the gross margin (revenue less effective operational cost), net margin (revenue less total operating expenses) used by Lopes et al. (2004b, 2009, 2011, 2016), Carvalho et al. (2009) e Teixeira Júnior (2014, 2015, 2016). Based on the indicators, we estimated the profitability, calculated as gross profit divided by total revenue, multiplied by 100 (Profitability $(\%)=$ Gross profit $\div$ Total revenue $) \times 100)$, and the return, calculated as the gross profit divided by the sum of total assets and effective operational costs, multiplied by 100 (Return $(\%)=$ Gross profit $\div$ (Total assets + Effective operational costs $) \times 100$ ) (SEBRAE, 1998).
In the statistical analyses, based on the work of Lopes et al. (2004b), the independent variables are divided into zootechnical variables, economic variables, components of the effective operational cost (EOC) (the sum of the amounts spent on food, labor, energy, health, milking, artificial insemination, taxes, and miscellaneous expenses), and total cost (TC) (the sum of the fixed and variable costs). The dependent variables are net margin (R\$) and profitability (\%). In order to evaluate the effect of the independent variables on the dependent variables, we employ a multiple linear regression model, and use a stepwise method to identify the independent variables that have the greatest influence. The stepwise method was chosen because of the high number of independent variables in the model, and because it enables us to identify those that have the most impact on the dependent variables (MAROCO, 2010).

The multiple linear regression equation is defined as follows:

$$
\mathrm{Yc}=\mathrm{a}+\mathrm{b} 1 \mathrm{x} 1+\mathrm{b} 2 \mathrm{x} 2+\ldots+\mathrm{bkxk}
$$

where $\mathrm{a}$ is the intercept on the y-axis, bi is the angular coefficient of the $\mathrm{i}$-th variable, and $\mathrm{k}$ is the number of independent variables. Then, the coefficient of determination, adjusted by the degrees of freedom (adjusted R-squared), is used to measure the variability in the dependent variable caused by the independent variables. Furthermore, we assume normality, homogeneity, and the independence of errors. The first two assumptions are validated graphically, while the independence assumption is validated using the Durbin-Watson statistic. The variance inflation factor (VIF) is used to check for multicollinearity, as described by Maroco (2010). All statistical analyses were performed using SPSS, version 20.0.

\section{Results and Discussion}

The mean stock rate, percentage of lactating cows, and percentage of cows in the overall herd 
for all DUs was $5.3 \mathrm{head} / \mathrm{ha}, 75.1 \%$, and $63.4 \%$, respectively. In the study by Lima et al. (2012), who conducted an economic analysis of milk production and a survey of the main productivity indices for a dairy farm in the interior of Ceará in 2011, these values were 8.51 head/ha, $78.12 \%$, and $62.91 \%$, respectively. The mean ratio of matrices per labor for all DUs was 16.43, which was higher than the value of 15.30 found by Lopes et al. (2009), but lower than the value of 78.6 found by Lima et al. (2012). Although all DUs showed a positive net margin, the mean profit was $-6.94 \%$, whereas in the studies by Lima et al. (2012) and Lopes et al. (2009), the mean profits were 6.67 and $17.46 \%$, respectively. These results indicate that to obtain satisfactory profitability, it is necessary to have economies of scale and good productivity rates by area, and to avoid investments in capital goods that will not have a positive influence on milk productivity. The producer must have adequate infrastructure, the minimum sufficient for production, and must have the largest possible ratio of matrices to labor, where a larger value indicates a greater "dilution" of the asset value in the inventory matrix. In addition, producers must increase production to use the least amount of land, because not doing so has a direct negative influence on profitability.

Descriptive statistics (mean, minimum value, maximum value, and standard deviation) were used to describe the zootechnical and economic indices of the 20 DUs that were "Full Bucket" program participants in the Rio de Janeiro State in 2011, as shown in Table 1.

Table 1. Descriptive statistics of zootechnical and economic indicators of 20 DUs in the "Full Bucket" program in Rio de Janeiro State in 2011.

\begin{tabular}{|c|c|c|c|c|}
\hline Specification & Mean & SD & Minimum & Maximum \\
\hline Ratio of matrices to labor (un.) & 16,43 & 9,93 & 4,83 & 37,17 \\
\hline Ratio of total herd to labor (un.) & 31,83 & 30,39 & 6,67 & 131,67 \\
\hline Animals/production area destined to milk activity (AU/ha) & 5,29 & 4,40 & 1,52 & 17,79 \\
\hline Lactating cows $(\%)$ & 75,13 & 10,01 & 52,98 & 88,75 \\
\hline Cows in the herd $(\%)$ & 63,43 & 17,14 & 27,34 & 100,00 \\
\hline Lactating cows in the herd $(\%)$ & 48,11 & 16,21 & 19,43 & 88,75 \\
\hline Daily animal productivity (kg/day) & 11,76 & 3,16 & 5,42 & 16,47 \\
\hline Animal production per area $(\mathrm{kg} / \mathrm{ha} /$ year $)$ & $10.016,92$ & $15.633,05$ & 591,03 & $71.126,00$ \\
\hline Break-even (kg milk/day)* & $2.123,97$ & $5.462,05$ & 78,44 & $20.761,78$ \\
\hline Operational break-even (kg milk/day)/day * (kg) & 762,99 & $1.967,47$ & 36,04 & $7.438,90$ \\
\hline Number of lactating cows per area destined to milk activity (head/ha) & 2,88 & 3,07 & 0,00 & 13,33 \\
\hline Milk production/labor (kg/service) & 142,87 & 96,55 & 48,28 & 446,24 \\
\hline Labor amount (contracted or family) & 1,55 & 0,69 & 1,00 & 3,00 \\
\hline Proportion of family labor in TOC (\%) & 20,06 & 14,46 & 0,00 & 45,88 \\
\hline Proportion of EOC in TOC $(\%)$ & 68,98 & 13,71 & 45,16 & 91,77 \\
\hline Proportion of depreciation in TOC $(\%)$ & 10,96 & 2,36 & 7,83 & 15,61 \\
\hline
\end{tabular}

* Break-even is the quantity of milk production that should be produced so that the total revenue value is equal to the total cost (LOPES; CARVALHO, 2000).

With regard to the zootechnical indicators, the model found that $70.50 \%$ of the total variability in net margin was represented by milk production by labor, and that an increase of $1 \mathrm{~kg}$ of milk per labor (employed or family member) per service would result in an increase of $\mathrm{R} \$ 151.60$ innet margin (see Table 2). This is because increasing the amount of milk produced using the same amount of hired labor reduces the means (unit) production costs and, thus, increases revenue. The increase in the net margin value, if positive, means that the revenue obtained is sufficient to cover the total operating cost, which allows the economic stability of the activity and signals the possibility of growth. 
Table 2. Multiple linear regression analysis of significant zootechnical indicators, descriptive levels of probability (P-value), and determination coefficients $\left(\mathrm{R}^{2}\right)$ of net margin, profitability, and return of 20 DUs in the "Full Bucket" Program in the Rio de Janeiro State in 2011.

\begin{tabular}{ccccc}
\hline Dependent Variable & Independent Variable & Regression & $\mathrm{P}$ & $\mathrm{R}^{2}$ \\
\hline $\begin{array}{c}\text { Net margin } \\
\text { (R\$) }\end{array}$ & Milk production/labor (kg/service) & $\mathrm{Y}=-5789,0+151,6 \mathrm{X}$ & $<0,010$ & 0,705 \\
& & & & \\
Profitability (\%) & Productivity (kg/animal/day) & $\mathrm{Y}=-63,7+5,1 \mathrm{X}$ & $<0,010$ & 0,455 \\
& & & & \\
& $\mathrm{X}_{1}$ Productivity (kg/animal/day) & $\mathrm{Y}=-17,2+1,3 \mathrm{X}_{1}+$ & $<0,010$ & 0,617 \\
Return (\%) & $\mathrm{X}_{2}$ Calves + steers + bulls (head) & $0,2 \mathrm{X}_{2}$ & $<0,010$ & \\
\hline
\end{tabular}

$\mathrm{Y}=$ Dependent variable

$\mathrm{X}=$ Independent variable(s).

In this study, the average milk production per labor force of all UDs was $142.87 \mathrm{~kg} /$ day (see Table 1), which is lower than the $246.12 \mathrm{~kg} /$ day found by Schiffler et al. (1999). The latter study evaluated four production systems in São Paulo, in herds with genetic patterns of at least 7/8 Dutch-zebu blood levels, in which all were selected for the Dutch breed. In these herds, concentrated supplementation was carried out throughout the year, based on the milk production, with increased supplements of corn silage in the dry period. Note that the average production observed in this study $(142.87 \mathrm{~kg} /$ day $)$ is near what was found by Lopes et al. (2004a), who studied 16 milk production systems in the Lavras region in the south of the state of Minas Gerais. Furthermore, the average milk production identified by our regression equation $(142,87 \mathrm{~kg} /$ day) results in a net margin of $\mathrm{R} \$ 15.870,10$. In addition, in order to obtain a zero net margin using our regression equation, the average milk production should be $38,19 \mathrm{~kg} /$ day.

Thus, the model found that $45.50 \%$ of the variability in profitability is represented by animal productivity per day (Table 2). Each additional kilogram of milk produced per day would increase profitability by $5.10 \%$. Such information is important and indicates that having additional productive animals can result in greater profitability. Increased productivity can be achieved, among other ways, in the short term by improvements in nutrition.
Nevertheless, according to Lopes et al. (2004b), Lopes et al. (2005), and Lopes et al. (2008), we need to consider the food given to the animals carefully, because this has a significant impact on the effective operational cost and, consequently, profitability.

Animal productivity per day had the greatest influence on production systems, followed by the number of males for sale, and represented $61.70 \%$ of the variability in returns (Table 2). An increase in animal productivity per day resulted in an increase of $1.30 \%$ in the return, and each additional head of calves, steers, and bulls resulted in an increase of $0.20 \%$ in the return. If we consider the standardized coefficient of the two variables, animal productivity $(0.782)$ has a greater impact on profitability than does the number of males (0.357). Whereas the impact of profitability is so small that the producer should focus on increasing animal productivity per day. It is worth mentioning that the sale of calves at weaning contributed significantly to the positive profitability, representing $25.0 \%$ of the total income (MORAES et al., 2004).

A reduction in mean total operating costs (i.e., per kilogram of produced milk) promotes improvements in the net margin. According to Lopes et al. (2008), there are two ways to reduce the mean, or unitary, total operating costs of an operation: increasing efficiency and increasing the scale of production. Thus, feeding animals, which had the greatest economic impact on EOC, should 
be well planned to meet animals' daily nutritional requirements, without compromising heir health and daily milk production. As suggested by Alvim et al. (1997), Cardoso et al. (2009), and Rennó et al. (2008), bulk production with quality becomes a viable option and promotes a reduction in feed costs. Thus, a good quality pasture would meet part of the nutritional needs of animals and require only concentrated supplements, depending on each animal's productivity and nutritional requirements. However, according to Rennó et al. (2008), income generation is proportional to the cow production level, and in the assessment per unit area, milk production and revenue are strongly influenced by the carrying capacity of the pasture and the forage productivity that make up feed strategies. In many cases, especially on small properties, intensifying production would reduce the costs of producing a higher volume of milk. According to Schiffler et al. (1999), the intensity of production of pasture areas can be measured by the stock rate and animal productivity per area.

The value of assets, excluding the cost of land, is another factor that had a negative influence on net margin, and should be minimized. Therefore, it is recommended that producers not invest in assets that do not have a positive influence on animal productivity, such as oversized plants and unnecessary machinery and equipment, and that do not promote increased economic returns. According to Lopes et al. (2009), the larger the asset values of machinery, equipment, and improvements, the greater are the amounts of depreciation. While not a disbursement, according to Lopes et al. (2008), depreciation affects the cash reserve value that should be used to replenish capital assets (facilities, equipment, etc.) at the end of their useful life, where the producer replaces these assets in order to continue the production process. A higher financial reserve (depreciable value of goods) means a lower net margin. In addition, these goods increase effective operational costs because of the maintenance they require. On average, depreciation accounted for $10.96 \%$ of the TOC. Although in the literature there is no information on the ideal value for this technical indicator, it can be said that the efficiency of utilization of the assets of the patrimony of the production systems studied in this research was higher than the $14.37 \%$ obtained by Lopes et al. (2004a).

With regard to profitability (Table 3), the model found that $73.60 \%$ of the it total variability was represented, in descending order of impact (representativeness), by milk revenue, total operating costs, asset value per lactating matrix, and the land value in the inventory. This means that each additional $\mathrm{R} \$ 1.00$ of milk revenue is expected to increase profitability by $6.5 \%$, each additional $\mathrm{R} \$ 1.00$ in total costs decreases profitability by $5.1 \%$, each additional $\mathrm{R} \$ 1.00$ in property value per lactating matrix increases profitability by $3.8 \%$, and each additional $\mathrm{R} \$ 1.00$ of land value in inventory decreases profitability by $2.3 \%$. These results are extremely important, because they can help producers examining their operations, as well as those who wish to start planning efficiently by maximizing the resources available to the dairy farm. To increase profitability, producers should focus on milk revenue and reducing total costs. To obtain higher revenues, producers should produce a greater volume of milk and employ good manufacturing practices (PAIXÃO et al., 2014) in order to produce better quality milk, free from contamination and with a greater content of total solids, and to earn the subsidies (DEMEU et al., 2011; LOPES et al., 2012) offered by the market for the best milk quality. In terms of diluting total costs, producers should be efficient, seeking to improve the zootechnical indices of production and reducing total unit costs (fixed and variable costs). To do so, one option is to reduce the proportion of land assets in inventory, using land more efficiently to increase milk production and, thus, diluting fixed costs. One of the technical indices that measures land-use efficiency, according to Lopes (2003), is the milk yield/ha/year. This is an indicator of the efficient use 
of foraging resources and the productive potential of the herd. The mean of all DUs was $10,017 \mathrm{~kg} / \mathrm{ha} /$ year, which was lower than the value of $15,200 \mathrm{~kg} /$ ha/year found by Lima et al. (2012), whose results showed a high rate of grazing capacity, depending on the cultivation of productive forage and the use of fertilizer and irrigation.

Table 3. Linear regression analysis of significant economic indicators, descriptive levels of probability (P-value) and determination coefficients $\left(\mathrm{R}^{2}\right)$ of profitability, and return of 20 DUs in the "Full Bucket" Program in the Rio de Janeiro State in 2011.

\begin{tabular}{ccccc}
\hline $\begin{array}{c}\text { Dependent } \\
\text { variable }\end{array}$ & Independent variable & Regression & $\mathrm{P}$ & $\mathrm{R}^{2}$ \\
\hline & $\mathrm{X}_{1}$ Asset value per (R\$) matrix in lactation (R\$) & & $<0,010$ \\
Profitability (\%) & $\mathrm{X}_{2}$ Milk revenue (R\$) & $\mathrm{Y}=-4,3+3,8 \mathrm{X}_{1}+$ & $<0,010$ & 0,736 \\
& $\mathrm{X}_{3}$ Total cost (R) & $6,5 \mathrm{X}_{2}-5,1 \mathrm{X}_{3}-2,3 \mathrm{X}_{4}$ & $<0,010$ & 0,037 \\
& $\mathrm{X}_{4}$ Ratio of land valueto inventory (\%) & & \\
& & & $<0,010$ \\
Return (\%) & $\mathrm{X}_{1}$ Asset value per kg of milk sold (R\$) & $\mathrm{Y}=12,3-8,1 \mathrm{X}_{1}+$ & $<0,010$ & 0,541 \\
& $\mathrm{X}_{2}$ Asset value in land/ha (R) & $0,0001 \mathrm{X}_{2}-4,1 \mathrm{X}_{3}$ & 0,023 & \\
\hline
\end{tabular}

$\mathrm{Y}=$ Dependent variable

$\mathrm{X}=$ Independentvariable(s).

With regard to economic return, the model found that $54.1 \%$ of the total variability was represented by the value of assets per kilogram of milk sold, the value of assets on land, and the proportion of livestock value in the inventory of farms (Table 3 ). The results showed that each additional $\mathrm{R} \$ 1.00$ in asset value per kilogram of milk sold represents a decrease of $8.1 \%$ in return, each additionalR $\$ 1.00$ in land value per hectare results in an increase of $0.0001 \%$ in return, and a $1 \%$ increase in the proportion of livestock in inventory results in a decrease of $4.10 \%$ in return. These facts are explained by assets, which, in general, do not contribute directly to production or revenue generation. Improvements such as a milking parlor with a moat and management areas with cement flooring can contribute to the welfare of the producer and the animals. However, other properties with fewer cows can produce the same amount of milk in simple structures and with the same level of hygiene. Here, the property with the simple structure will have a greater financial return. Thus, it is essential to plan a dairy property because the activity involves many variables that directly affect the result.
With regard to the asset land value by area, in Reais ( $\mathrm{R} \$ / \mathrm{ha})$, we note that the size of the area has a positive effect on the return of the operation (Table 3). This is because a bigger area can support a greater number of animals, achieving higher milk production and more animals for commercialization, as well as an increase in the scale of production, which, according to Lopes et al. (2006), have a positive influence on return.

With regard to the value of livestock in inventory, the number of working animals adversely affected the return (Table 3). This is because these animals do not generate revenue directly, but do incur expenses. However, the use of these animals reduces operating costs, which reduces the need for outsourced services and lowers production costs by replacing the use of machinery and equipment. Depending on the herd size, the volume of milk produced, and the scale of production, farmers need to conduct administrative and financial analyses when deciding whether to keep such animals.

An analysis of the impact of the statistically significant $(p<0.05)$ EOC components $(R \$$; see 
Table 4) on net margin, after the adjustment of the regression models, the model found (in descending order of importance) that $83 \%$ of the total variability in net margin was represented by protein commercial concentrates, energy concentrates, and the number of bulk purchases. Thus, each additional $\mathrm{R} \$ 1.00$ spent in commercial concentrates resulted in an increase ofR $\$ 12.80$ in net margin, each additional $\mathrm{R} \$ 1.00$ spent on energy concentrates resulted in an increase of $\mathrm{R} \$ 0.90$ in net margin, which, if not considered the other benefits of this type of food, would not be so advantageous; and each R \$ 1.00 more in the value of the bulky purchased would decrease by $\mathrm{R} \$ 27.00$ in the net margin, which indicates the importance of producing bulky in the property. The DUs that used the most concentrates were those that produced larger volumes of milk and, consequently, those which had the highest net margin values. With regard to bulk purchases, it was expected that the DUs that needed to buy food in bulk for their cows would have the lowest net margin. This showed that there were failures in planning for bulk production. That is, the bulk production in the DUs was not enough to meet the demand of animals, requiring the purchase of additional food, or there was insufficient time for forage production and harvesting. Bulk purchases of food tend to be more expensive because they include other costs, such as freight and outsourced services, among others.

Table 4. Multiple linear regression analysis of the indicators, significant EOC elements in R $\$$, descriptive levels of probability (P-value), and determination coefficients $\left(\mathrm{R}^{2}\right)$ of the significant indicators compared to the net margin of 20 DUs in the "Full Bucket" Program in the Rio de Janeiro State in 2011.

\begin{tabular}{ccccc}
\hline Dependent Variable & Independent Variable & Regression & $\mathrm{P}$ & $\mathrm{R}^{2}$ \\
\hline \multirow{3}{*}{ Net margin } & $\mathrm{X}_{1}$ EOCenergy concentrate $(\mathrm{R} \$)$ & $\mathrm{Y}=-1125,1+0,9 \mathrm{X}_{1}+$ & $<0,01$ & \\
& $\mathrm{X}_{2}$ EOCcommercial concentrate $(\mathrm{R} \$)$ & $12,8 \mathrm{X}_{2}-27,0 \mathrm{X}_{3}$ & 0,01 & 0,83 \\
& $\mathrm{X}_{3}$ EOCBulk purchases(R\$) & & 0,016 & \\
\hline
\end{tabular}

$\mathrm{Y}=$ Dependent variable

$\mathrm{X}=$ Independent variable(s).

When evaluating the components of TOC (Table 5), the model found that $50.80 \%$ of the total variability in net margin related to the participation of family labor (as a percentage of TOC). Here, a1\% increase meant a decrease of $\mathrm{R} \$ 1,160.00$ in net margin. This is because most DUs use this kind of labor and produce on a small scale, with this labor being idle. The mean of all DUs of the ratio of family labor to total operating costs was higher than the $3 \%$ reported by Lopes et al. (2004b) and the $10 \%$ found by Lopes et al. (2006). 
Table 5. Multiple linear regression analysis of the indicators, significant TC elements (in\%), descriptive levels of probability (P-value), and determination coefficients $\left(\mathrm{R}^{2}\right)$ of the significant indicators of net margin, profitability, and return of 20 DUs in the "Full Bucket" Program in the Rio de Janeiro State in 2011.

\begin{tabular}{ccccc}
\hline Dependable Variable & Independent Variable & Regression & P & $\mathrm{R}^{2}$ \\
\hline \multirow{2}{*}{ Net Margin } & Ratio of family labor to TOC (R\$) & Y=32806,9- & $<0,01$ & 0,508 \\
& Ratio of actual operating costs to TOC (\%) & $\mathrm{Y}=-75,7+1,2 \mathrm{X}$ & $<0,01$ & 0,411 \\
Profitability & Ratio of actual operating costs to TOC (\%) & $\mathrm{Y}=-15,4+0,26 \mathrm{X}$ & $<0,01$ & 0,290 \\
\hline
\end{tabular}

$\mathrm{Y}=$ Dependent variable

$\mathrm{X}=$ Independent variable(s).

With regard to profitability, the model found that $41.10 \%$ of the total variability was related to the proportion of actual operating costs in TOC. Here an additional 1\% meant an increase of $1.20 \%$ in the profitability of milk production (Table 5). To improve these economic results and financial indicators, the dairy should reduce fixed costs in order to increase the proportion of EOC in TOC. Higher asset values in machinery and equipment mean lower profitability (Table 5), and vice versa. Thus, managers need to invest financial resources in milk production in the simplest way possible, while assessing whether they really need the machinery or equipment, based on the costs of production and its effectiveness, because high asset values may increase production costs, if the cost-benefit ratio is not satisfactory (LOPES et al., 2004b). The mean ratio of EOC to TOC for all DUs was 52.52\%, which was lower than the value of $87.50 \%$ found by Lima et al. (2012).

With regard to economic return, the model found that $29.00 \%$ of it variability was related to the proportion of actual operating costs in TOC. Here, an additional $1 \%$ increased the return by $0.26 \%$ (Table 5), for the same reasons given for profitability. Thus, investing in assets, including land, can negatively influence profitability and the return if it is not well planned, because greater financial capital expenditure on investments in property mean higher asset costs (returns on invested capital and depreciation).

\section{Conclusions}

The results obtained were extremely important, as they helped the producers who are exploring the activity, as well as those who wish to start to plan efficiently, maximizing the resources available for the dairy exploration.

The factors that have the greatest positive influence on net margin are milk production by labor, total revenue, protein commercial and energy concentrates, and ratio of labor to TOC.

The factors that have most negative affect on net margin are total operating costs, the value of property (excluding land), bulk purchases, and the ratio of family labor to TOC.

Animal productivity per day, the asset value by lactation matrix, milk revenue, and the proportion of energy concentrates have the most positive influence on profitability, while TOC and the ratio of land value to inventory have the greatest negative influence.

Regarding profitability, the items that most influence positively are the number of males, the animal productivity per day and the value immobilized on land per area, while the items that most negatively influence are the immobilized value per $\mathrm{kg}$ of milk sold and representativeness value of livestock in the inventory. 


\section{Acknowledgements}

The authors would like to thank the Minas Gerais State Research Foundation (Fundação de Amparo à Pesquisa do Estado de Minas Gerais - FAPEMIG) and the National Council for Scientific and Technological Development (Conselho Nacional de Pesquisa e Desenvolvimento Tecnológico - CNPq) for the financial support for the present study.

\section{References}

ALVIM, M. J.; VILELA, D.; LOPES, R. S. Efeito de dois níveis de concentrado sobre a produção de leite de vacas da raça Holandesa em pastagem de Coast-cross. Revista da Sociedade Brasileira de Zootecnia, Viçosa, v. 26, n. 5, p. 967-975, set./ out. 1997.

BORGES, M. S.; GUEDES, C. A. M.; ASSIS, R. L. Um estudo do Projeto Balde Cheio como vetor de desenvolvimento sustentável do pequeno produtor de leite. Revista Brasileira de Agropecuária Sustentável, Viçosa, v. 1, n. 1, p. 151-161, 2011.

CAMARGO, A. C.; NOVO, A. M. Training of extension technicians and producers in intensive milk production - technology transfer (Full Bucket Project). São Carlos: Embrapa Pecuária Sudoeste, 2012. 1 p. Available at: $<$ https://ainfo.cnptia.embrapa.br/digital/bitstream/ item/72409/1/PROCI-2012.00199.pdf>. Accessed at: 28 nov. 2016.

CARDOSO, R. C.; PAIVA, P. C. A.; VILELA, D. Desempenho de vacas da raça Holandesa em pastagem de Cynodon dactylon cv. Coast-cross suplementada com concentrado. Ciência e Agrotecnologia, Lavras, v. 33, n. 6, p. 1663-1670, nov./ dez. 2009.

CARVALHO, F. de M.; RAMOS, O. E.; LOPES, M. A. Análise comparativa dos custos de produção de duas propriedades leiteiras no município de Unai - MG, no período de 2003 e 2004. Ciência e Agrotecnologia, Lavras, v. 33, p. 1705-1711, 2009. Edição Especial.

DEMEU, F. A.; LOPES, M. A.; COSTA, G. M.; ROCHA, C. M. B. M.; SANTOS, G.; FRANCO NETO, A. Influência do descarte involuntário de matrizes no impacto econômico da mastite em rebanhos leiteiros. Ciência e Agrotecnologia, Lavras, v. 35, n. 1, p. 195-202, 2011.
LIMA, F. W. R.; OLIVEIRA, P. J. D.; PEREIRA, E. S.; FONTENELE, R. M.; ARRUDA, P.C. L.; PACHECO, W. F.; GUERREIRO, A. B. Índices de produtividade e análise econômica da produção de leite a pasto no interior do Ceará. Acta Veterinaria Brasilica, Mossoró, v. 6, n. 3, p. 186-191, 2012.

LOPES, M. A. Sistemas computacionais para cálculo do custo de produção do leite e carne. Lavras: FAEPE/ PROEX, 2003. 35 p. (Apostila).

LOPES, M. A.; CARDOSO, M. G.; CARVALHO, F. M.; DIAS, A. S.; LIMA, A. L. R.; CARMO, E. A. Resultados econômicos da atividade leiteira na região de Lavras (MG) nos anos 2004 e 2005: um estudo multicasos. Arquivo Brasileiro de Medicina Veterinária e Zootecnia, Belo Horizonte, v. 60, n. 2, p. 428-435, 2008.

LOPES, M. A.; CARVAlHO, F. de M. Custo de produção do leite. Lavras: UFLA, 2000. 42 p. (Boletim Agropecuário, 33).

LOPES, M. A.; DEMEU, F. A.; ROCHA, C. M. B. M.; COSTA, G. M.; FRANCO NETO, A.; SANTOS, G. Avaliação do impacto econômico da mastite em rebanhos bovinos leiteiros. Arquivos do Instituto Biológico, São Paulo, v. 79, n. 4, p. 477-483, 2012.

LOPES, M. A.; DIAS, A. S.; CARVALHO, F. de M.; LIMA, A. L. R.; CARDOSO, M. G.; CARMO, E. A. Resultados econômicos de sistemas de produção de leite com diferentes níveis tecnológicos na região de Lavras, MG nos anos 2004 e 2005. Ciência e Agrotecnologia, Lavras, v. 33, n. 1, p. 252-260, 2009.

LOPES, M. A.; LIMA, A. L. R.; CARVALHO, F. M.; REIS, R. P.; SANTOS, I. C.; SARAIVA, F. H. Controle gerencial e estudo da rentabilidade de sistemas de produção de leite na região de Lavras (MG). Ciência e Agrotecnologia, Lavras, v. 28, n. 4, p. 883-892, 2004a.

Efeito da escala de produção nos resultados econômicos de sistemas de produção de leite na região de Lavras (MG): um estudo multicasos. Boletim de Indústria Animal, Nova Odessa, v. 63, n. 3, p. 177-188, 2006.

Efeito do tipo de sistema de criação nos resultados econômicos de sistemas de produção de leite na região de Lavras (MG). Ciência e Agrotecnologia, Lavras, v. 28, n. 5, p. 1177-1189, 2004b.

. Resultados econômicos de sistemas de produção de leite com diferentes níveis tecnólogicos na região de Lavras (MG). Arquivo Brasileiro de Medicina Veterinária e Zootecnia, Belo Horizonte, v. 57, n. 4, p. 485-493, 2005. 
LOPES, M. A.; SANTOS, G. dos; RESENDE, M. C.; CARVALHO, F. de M.; CARDOSO, M. G. Estudo da rentabilidade de sistemas de produção de leite na região de Nazareno (MG)6cON. Ciência Animal Brasileira, Goiânia, v. 12, n. 1, p. 58-69, 2011.

LOPES, M. A.; MORAES, F.; CARVALHO, F. M.; PERES, A. A. C.; BRUHN, F. R. P.; REIS, E. M. B. Effect of technical indexes on cost-effectiveness in dairy farms participating in the "Balde Cheio" program at different stages of production. Semina: Ciências Agrárias, Londrina, v. 37, n. 6, p. 4235-4242, nov./dez. 2016.

MAROCO, J. Análise estatística com utilização do SPSS. 3. ed. Lisboa: Sílabo, 2010. 822 p.

MORAES, A. C. A.; COELHO, S. G.; RUAS, J. R. M.; RIBEIRO, J. C. V. C.; VIEIRA, F. A. P.; MENEZES, A. C. Technical and economic study of a milk production system with crossbred F1 Holstein-Zebu cattle. Brazilian Archive of Veterinary Medicine and Zootechnics, Belo Horizonte, v. 56, n. 6, p. 745-749, dec. 2004.

OLIVEIRA, A. S.; CUNHA, D. N. F. V.; CAMPOS, J. M. S.; VALE, S. M. L. R.; ASSIS, A. J. Identificação e quantificação de indicadores-referência de sistemas de produção de leite. Revista Brasileira de Zootecnia, Viçosa, MG, v. 36, n. 2, p. 507-516, 2007.

PAIXÃO, M. G.; LOPES, M. A.; PINTO, S. M.; ABREU, L. R. Impacto econômico da implantação das boas práticas agropecuárias relacionadas à qualidade do leite. Revista Ceres, Viçosa, MG, v. 61, n. 5, p. 612-621, set./ out. 2014.

RENNÓ, F. P.; PEREIRA, J. C.; LEITE, C. A. M.; RODRIGUES, M. T.; CAMPOS, O. F.; FONSECA, D. M.; RENNÓ, L. N. Eficiência bioeconômica de estratégias de alimentação em sistemas de produção de leite: produção por animal e por área. Revista Brasileira de Zootecnia, Viçosa, MG, v. 37, n. 4, p. 743-753, 2008.

SCHIFFLER, E. A.; MÂNCIO, A. B.; GOMES, S. T. Efeito da escala de produção nos resultados de produção de leite B no estado de São Paulo. Revista Brasileira de Zootecnia, Viçosa, MG, v. 28, n. 2, p. 425-431, 1999.

SERVIÇO BRASILEIRO DE APOIO ÀS MICRO E PEQUENAS EMPRESAS - SEBRAE. Curso de capacitação rural. Goiânia: SEBRAE, 1998. 34 p.

TEIXEIRA JÚNIOR, F. E. P.; LOPES, M. A.; RUAS, J. R. M.; COSTA, M. D. da; PIRES, D. A. de A.; ROCHA JÚNIOR, V. R. Rentabilidade do uso de tecnologias em sistema de produção de leite com vacas $\mathrm{F} 1$ holandês $\mathrm{x}$ zebu. Revista Científica de Produção Animal, Areia, v. 16, n. 2, p. 79-88, 2014.

TEIXEIRA JÚNIOR, F. E. P.; LOPES, M. A.; RUAS, J. R. M.; SILVA, M. A. O. Efeito dos manejos de amansamento de primíparas no pré-parto e do maior peso vivo ao parto na rentabilidade da atividade leiteira. Revista Brasileira de Ciência Veterinária, Niterói, v. 23, n. 1-2, p. 81-86, 2016.

TEIXEIRA JÚNIOR. F. E. P.; LOPES, M. A.; RUAS, J. R. M. Efeito da idade de aquisição de fêmeas para reposição na rentabilidade da atividade leiteira. Boletim de Indústria Animal, Nova Odessa, v. 77, n. 1. p. 59-68, 2015.

YAMAZI, A. K.; MORAES, P. M.; VIÇOSA, G. N.; ORTOLANI, M. B. T.; NERO, L. A. Práticas de produção aplicadas no controle de contaminação microbiana na produção de leite cru. Bioscience Journal, v. 26, n. 4, p. 610-618, jul./ago. 2010. 
